\title{
Nuclease-Sensitive Element-Binding Protein 1
}

National Cancer Institute

\section{Source}

National Cancer Institute. Nuclease-Sensitive Element-Binding Protein 1. NCI Thesaurus. Code C93121.

Nuclease-sensitive element-binding protein 1 (324 aa, $36 \mathrm{kDa}$ ) is encoded by the human YBX1 gene. This protein plays a role in the mediation of mRNA splicing and transcriptional regulation. 